\title{
Studies on Islet Cell Regeneration, Hyperplasia and Intrainsular Cellular Interrelations in Long Lasting Streptozotocin Diabetes in Rats*
}

\author{
H. Steiner**, O. Oelz, G. Zahnd and E.R. Froegch \\ Institut d'Anatomie Pathologique, Université de Lausanne, Stoffwechsellaboratorium der Medizinischen Universitäts- \\ klinik Zürich, Policlinique Médicale Universitaire, Genève, Suisse
}

Received: July 20, 1970

Studies on islet cell regeneration, hyperplasia and intrainsular cellular interrelations in long-lasting streptozotocin diabetes in rats

Summary. Diabetes was induced in rats with various single i.v. doses of streptozotocin. The rats were killed 4-10 months thereafter. Marked hyperglycaemia, ketonaemia and a rise of plasma free fatty acids resulted. The weight increase was markedly reduced. There was a clear reciprocal correlation between the injected dose of the diabetogenic agent and plasma IRI. The same was true for the B-cell counts. There was a marked B-cell hypertrophy, whereas we found only slight indication for B-cell regeneration. In one animal a functioning $B$-cell adenoma devoloped and almost all the parameters tested were normalized. In the diabetic animals the $A_{2}$-cells were predominant in the islets of Langerhans and their mean nuclear diameters were increased. In the duodenal mucosa no increase in the number of glucagonocytes was found.

We interpret this activity of the glucagonocytes as a consequence of permanent and long-lasting hyperglycaemia.

Investigations sur la regénération et l'hyperplasie des cellules dans les îlots de Langerhans et sur les interrelations cellulaires intrainsulaires dans le diabète de longue durée provoqué par la streptozotocine chez le rat

Résumé. Par des doses différentes de Streptozotocine i.v. on provoque chez des rats un diabète d'une durée de 4 à 10 mois. On note une hyperglycémie sévère, une acétonémie et une augmentation modérée des acides gras. La prise de poids est diminuée de façon marquée. - Il existe une nette corrélation réciproque entre la quantité d'agent diabétogène injecté et l'insuline immunoréactive plasmatique (IRI). On trouve le même rapport entre le nombre des cellules $\mathbf{B}$ et la quantité de Streptozotocine. On note une corrélation directe entre le nombre des cellules B et l'IRI. - L'hypertrophie des cellules B est importante alors qu'on ne trouve que peu de signes de régénération des îlots et des cellules $\mathrm{B}$. - Chez un des rats on note l'apparition d'un adénome à cellules B fonctionnant, provoquant une normalisation du métabolisme glucidique. - Chez les animaux diabétiques, les cellules $A_{2}$ prédominent et le diamètre moyen des noyaux est augmenté. On ne note pas d'augmentation significative des glueagonocytes de la muqueuse duodénale.

Nous considérons que cette augmentation de l'activité des glucagonocytes est fonction de l'hyperglycémie per. manente et de longue durée.

Untersuchungen zur Inselzell-Regeneration, Hyperplasie und zu intrainsulären zellulären Beziehungen während eines Langzeit-Streptozotocin-Diabetes bei Ratten

Zusammenfassung. Mit verschiedenen Dosen von Streptozotocin i.v. wird bei Ratten ein 4--10 Monate dauernder Diabetes induziert. Es resultiert eine schwere Dauerhyperglykämie, Acetonämie und ein mäßiger Anstieg der freien Fettsäuren. Die Gewichtszunahme ist wesentlich reduziert. Es besteht eine klare reziproke Korrelation zwischen injizierter Menge des diabetogenen Agens und Plasma-IRI. Ein gleicher Zusammenhang besteht zwischen der Zahl der B-Zellen und Streptozotocin. Eine direkte Korrelation findet sich für B-Zell-Zahlen und IRI. Die B-Zellen sind ausgeprägt hypertrophisch, während sich nur geringe Anhaltspunkte für B-Zellregeneration finden lassen. Bei einem Tier entwickelt sich ein funktionierendes B-Zelladenom mit konsekutiver Normalisie. rung des pathologischen Zuckerstoffwechsels. - Bei den diabetischen Tieren überwiegen die $\mathrm{A}_{2}$-Zellen stark, und gleichzeitig ist der mittlere Kerndurchmesser vergrößert. In der Duodenalschleimhaut besteht keine signifikante Vermehrung der Glucagonocyten.

Wir interpretieren diese Aktivitätszunahme der Glucagonocyten als Ausdruck der fixierten und langdauernden Hyperglykämie.

Key-words: Streptozotocin-diabetes, B-cell hyperplasia, B-cell regeneration, $\mathrm{A}_{2}$-cell hyperactivity, rat immunoreactive insulin, gut glucagonocytes, $\beta$-cytotrophy.
The still controversial reports on regenerative activity and neoformation of B-cells in diabetes [14, 20, $21,22,23,28]$ and the discussions about the function of the glucagonocytes $\left(\mathrm{A}_{2}\right.$-cells) in hyperglycaemia have encouraged us to study these phenomena morphologically and biochemically in rats rendered chronically diabetic by streptozotocin. Streptozotocin is a

* Reported in part at the annual meeting of the Schweiz. Gesellschaft für Pathologie, 31. 10. 1969

** Present address: Hugo Steiner, M. D.

Institute of Pharmacology,

University of Milano

32 via Vanvitelli

I-20129 Milano glucosamine derivative with well-known beta-cytotoxic properties [32, 17]. It has the advantage over alloxan. that the toxic side effects are of relatively little importance and that a long survival is possible.

\section{Material and Methods}

Twelve Osborne-Mendel rats pure bred, male and $6-8$ weeks old with an initial weight of $120-140 \mathrm{~g}$ survived for at least 4 months (mean 4.9 months) after a single intravenous injection of streptozotocin (kindly given to us by Dr. W.E. Dulin, the Upjohn Company, Kalamazoo, Mich. USA). 
The injected doses were $45-100 \mathrm{mg} / \mathrm{kg}$ body weight. Streptozotocin was dissolved in $0.9 \%$ saline and adjusted to $\mathrm{pH} 4$ with citric acid as described by Junod et al. [17]. It was prepared immediately before use and injected intravenously.

The animals were fed with regular chow (Nafag pellets) and water ad libitum.

For practical purposes we formed two groups of diabetic rats. Group 1 comprised 8 animals injected with relatively low doses of streptozotocin i.v., (45$65 \mathrm{mg} / \mathrm{kg}$ ); in Group II the rats received $85-100 \mathrm{mg} / \mathrm{kg}$ i.v. Group III consisted of 6 control animals of the same age. The animals were killed by decapitation in the fed state. Immunoreactive insulin (IRI) was determined in plasma by a double antibody method based on the Hales and Randle technique and using rat insulin standard (Novo Industries, Copenhagen). Plasma glueose was determined enzymatically, and acetone with the Galat reagent. Free fatty acids were assayed according to Gordon [8]. The pancreas was extirpated and 1 piece fixed in Bouin and another in Carnoy solution. The proximal duodenum was fixed in buffered $10 \%$ formalin. The fixed material was embedded in paraplast and $4-5 \mu$ thick sections were stained. types (see results section). In the duodenal mucosa, the number of Grimelius-positive cells is given as the number found in 100 completely and perpendicularly sectioned crypts as proposed by Funk et al. [6].

Karyometric studies were done in unselected islets using a magnification of 1250 times. 30 sectioned nuclei of each cell type were measured with a Zeiss ocular micrometer. By manipulation of the objective, the largest nuclear area was focused and the mean of two subsequent measurements determined. The largest and the smallest diameters were measured in oval nuclei. We corrected the diameters of non-spheric nuclei mathematically with the formula $\frac{a+b}{2}$, where a and $b$ are the two arbitrary units. 7 units are equal to $10 \mu$.

\section{Results}

One single i.v. injection of streptozotocin resulted in a marked increase in glycaemia. Acetonaemia of varying degree was present in all animals and a slight rise of plasma free fatty acids (FFA) was observed (table 1). The weight increase of these growing animals was markedly retarded in the diabetic rats, although

Table 1

\begin{tabular}{|c|c|c|c|c|}
\hline & $\begin{array}{l}\text { Group I } \\
45-65 \mathrm{mg} / \mathrm{kg}\end{array}$ & $\begin{array}{l}\text { Group II' } \\
85-100 \mathrm{mg} / \mathrm{kg}\end{array}$ & $\begin{array}{l}\text { Group III } \\
\text { controls }\end{array}$ & Unit \\
\hline $\begin{array}{l}\text { Glucose } \\
\text { FFA } \\
\text { IRT }\end{array}$ & $\begin{array}{c}659 \pm 62 \\
0.84 \pm 0.1 \\
32 \pm 12.8\end{array}$ & $\begin{array}{c}617 \pm 38.5 \\
0.71 \pm 0.07 \\
8.5 \pm 3.5\end{array}$ & $\begin{array}{c}165 \pm 24.2 \\
0.52 \pm 0.13 \\
141.2 \pm 61.3\end{array}$ & $\begin{array}{l}\mathrm{mg} / 100 \mathrm{ml} \\
\mu \mathrm{g} / \mathrm{ml} \\
\mu \mathrm{U} / \mathrm{ml}\end{array}$ \\
\hline $\begin{array}{l}\text { terminal } \\
\text { body weight } \\
\text { B-cells }\end{array}$ & $\begin{aligned} 227.3 & \pm 35.4 \\
9.7 & \pm \quad 4.33\end{aligned}$ & $\begin{array}{cc}156.5 & \pm 24.5 \\
3.1 & \pm 0.86\end{array}$ & $\begin{array}{cl}454 & \pm 36.7 \\
66 & \pm 3\end{array}$ & $\begin{array}{l}\mathrm{g} \\
\text { o\% total islet } \\
\text { cell count }\end{array}$ \\
\hline
\end{tabular}

a The case with the B-cell adenoma is not included.

In the pancreas, the B-cells were demonstrated with the Gomori-Runge stain [25] or with Ivic's Victoria blue method [16]. A-cells may be recognized with this method as well, but to separate the two A-cell-types we used Hellman and Hellerström's method [13] for the identification of $\mathrm{A}_{1}$-cells and the Grimelius method [9] for the $A_{2}$-cells (glucagonocytes). Serotonin cells were shown histochemically with the Masson-Hamperl technique [11] and with the Diazo coupling method [29]. Mast cells and Weichselbaum "Körnchen" [7] were identified with the Toluidine-blue method. The quantitative determinations of the cellular composition of the islets were performed in randomly selected islets by one of us not knowing the group to which the rats belonged. About 800 cells per pancreas were classified and differentially counted, the results for each cell type being given as a percentage of the whole cell population. Preliminary studies had shown that in our cases stereologic measurements were very difficult to interpret because of the existence of various B-cell the food and water intake was excessive. In one animal (injected with $85 \mathrm{mg}$ streptozotocin $/ \mathrm{kg}$ ), we found a normal terminal blood glucose value and the IRI was $78 \mathrm{U} / \mathrm{ml}$. It weighed $365 \mathrm{~g} 10$ months after the injection of the diabetogenic agent. Serial sections in the pancreas revealed the presence of a B-cell adenoma measuring $1.05 \mathrm{~mm}$ in diameter [Fig. 1]. We identified very fow silver-positive cells (less than 1\%) concentrated in one area of the adenoma. The largely overwhelming part of the tumour consisted of aldehyde-fuchsin positive cells. The remaining islets had the same repartition of islet cells $(4.19 \%$ B-cells) as the other cases, injected with high doses of streptozotocin. In another case, most of the $85 \mathrm{mg}$ streptozotocin $/ \mathrm{kg}$ was injected para. venously. This animal did not differ from the controls either morphologically or biochemically. It is therefore not included in the statistical analysis.

There was a clear reciprocal correlation between the injected doses of the diabetogenic agent and plasma IRI (Fig. 2). The B-cell counts were related in the 
same way to the amount of injected streptozotocin (Fig. 3a) and to the IRI in plasma (Fig. 3b). Most of the B-cells in strongly diabetic animals were very large, strongly degranulated and showed Weichselbaum "Körnchen", which are supposed to indicate an elevated synthetic activity of peptides [7]. Generally, a second B-cell population was observed, which appeared to be smaller in size and contained granules which were larger and more numerous (Fig. 4). In some

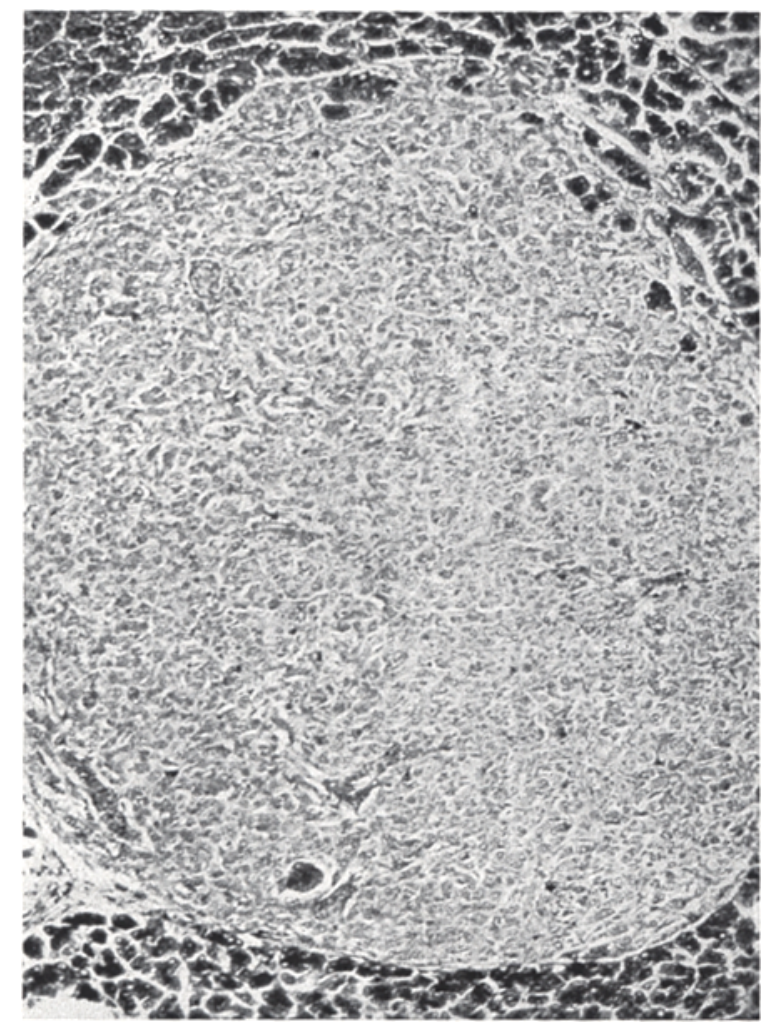

Fig. 1. B-cell adenoma developed in diabetic rat treated with $85 \mathrm{mg} / \mathrm{kg}$ streptozotocin i.v. For biochemical data see text. Gomori-Runge, 100:1

pancreases a few single cells were found scattered among the exocrine parenchyma which had the staining properties of B-cells (Fig. 5).

The percentage of B-cells in the islets was markedly reduced in all diabetic cases (Fig. 3) and their absolute number was also diminished since the total islet mass was not increased as may be derived from Fig. 6. Mitoses were not seen. Hydropic changes were infrequent $(0-0.5 \%$ of total cell count). A few areas of fibrosis were found and mast cells were infrequent. The number of non-granulated cells which could not be classified according to type was between 1 and $7.5 \%$ (mean $4.1 \%$ ) in the diabetic animals and between 0.6 and $2.5 \%$ (mean $1.5 \%$ ) in the controls. The usual rat islet structure with peripheral arrangement of the $A_{2}$-cells and with the $A_{1}$-cells scattered in the region between the $B$ and $A_{2}$-cells, appeared to be completely deranged in pancreases of diabetic rats.
The $A_{2}$-cells were predominant (Fig. 7) and scattered throughout the whole islet section surface. The mean nuclear diameters of the B-cells, measured in the Gomori-Runge stained sections, and of the $A_{2}$-cells (in Grimelius'stain) showed a marked increase in the

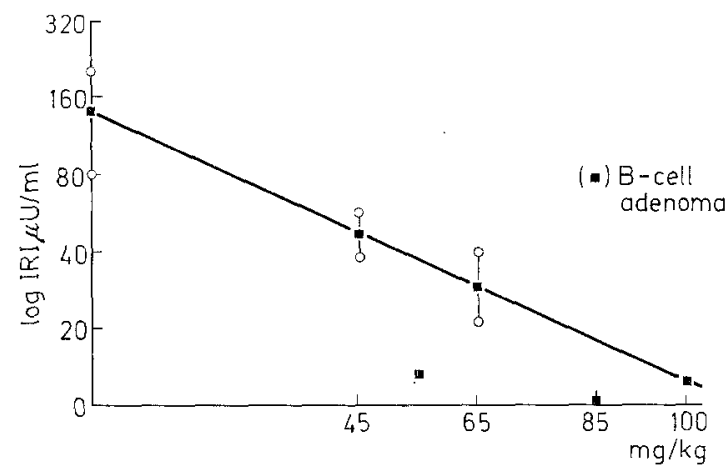

Fig. 2. Correlation between plasma IRI and injected doses of streptozotocin 5 months after treatment. Semilogarhithmic scale. Open cycles show the SEM

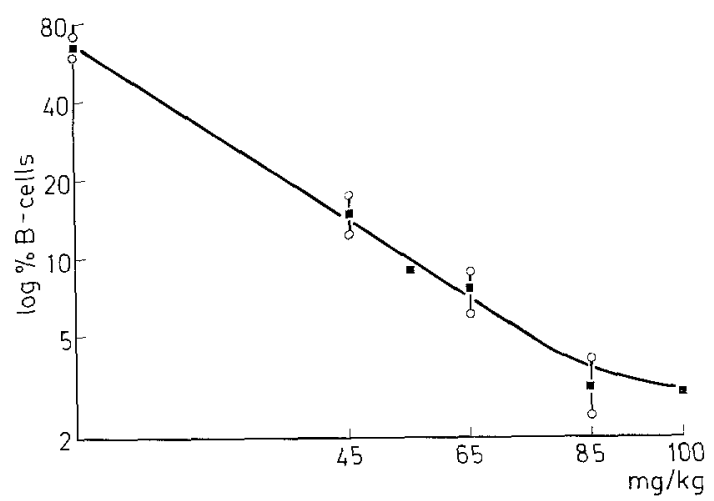

Fig. 3 a. Correlation between the percentage of B-cells in the islets of Langerhans and the injected doses of streptozotocin 5 months after treatment. Semilogarhithmic scale

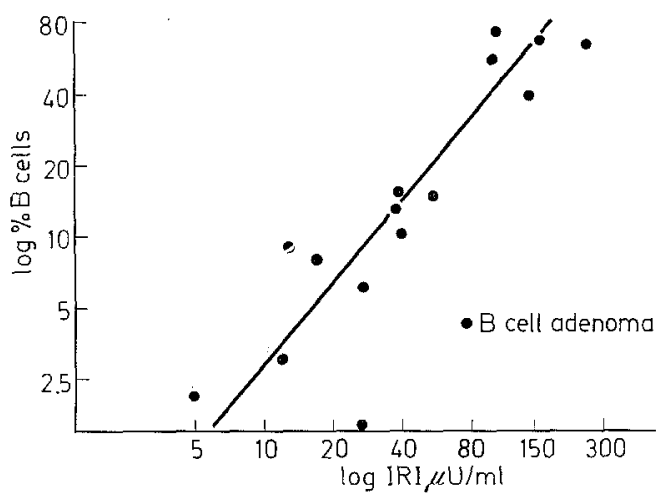

b. Correlation between the percentage of B-cells and the plasma IRI. Logarhithmic scale

diabetic animals (Fig. 8). We checked the validity of our results by measuring the $A_{1}$ and $A_{2}$-cell nuclear diameter together in the Gomori-Runge preparation. In the majority of cases the mean diameter of the A-cell 
nuclei was a little larger in the slides with the Grimelius technique $(+4.3 \%$; range -5 to $+14.7 \%)$, than stained in the Gomori-Runge preparations. For the

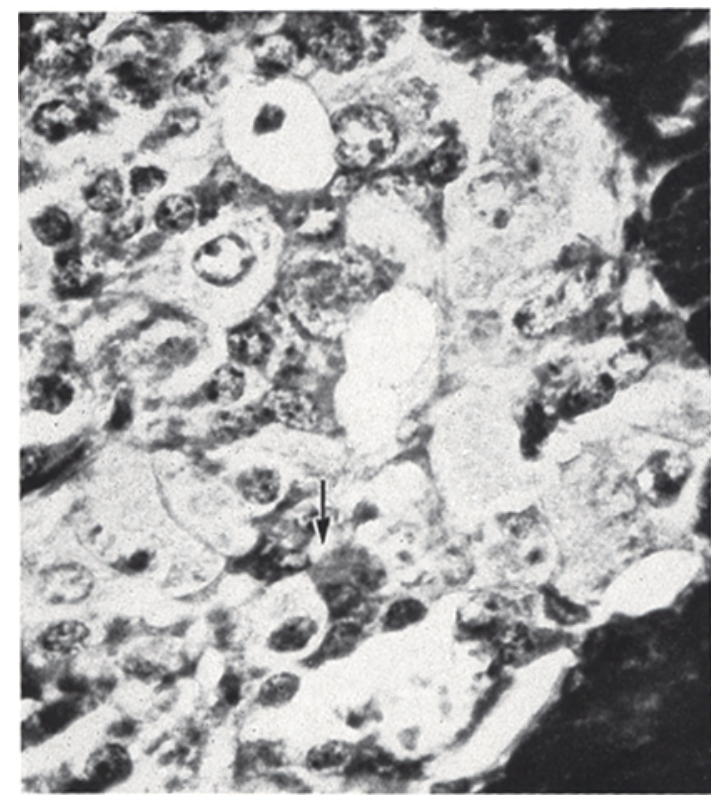

Fig. 4. Islet section from a diabetic rat after $45 \mathrm{mg} / \mathrm{kg}$ streptozotocin. 2 kinds of B-cells

1. large, almost completely degranulated ones

2. smaller, strongly granulated ones (arrow)

No. Ga 655, Gomori-Runge, 800:1
B-cells and slightly increased for $A_{2}$-cells $4.48 \pm 0.40$ units).

The duodenal argyrophil cells, as demonstrated by the Grimelius technique, were not significantly increased in the diabetic animals: $32.7 \pm 19.7$ cells/ 100 crypts in group I, $52.3 \pm 19.5$ in group II and $31.3 \pm 14.7$ in the control group III. Thin serial sections revealed that a part of the Grimelius-positive cells was also argentaffin; therefore more than one type of cells appears to be impregnated with Grimelius'silver reaction. The same is true for the HellerströmHellman stain.

\section{Discussion}

The diabetogenic effect of streptozotocin [32] is due to its marked $\beta$-cytotoxic activity [32, 17]. This action seems to be more specific than that of alloxan [17], and to have less general toxic side effects. Its action is also different from alloxan in several respects $[35,24]$. Junod and coworkers [18] have recently shown in detail the effect of streptozotocin in rats immediately and until 28 days after injection of the agent. The most striking result in our study is the uniformity of all changes in diabetic animals as long as 5 months and more after the injection of streptozotocin. A dose response curve between streptozotocin and plasma IRI and B-cell counts in the pancreas was still present (Fig. 2, 3a). A steady state seems to be established between the number of B-cells and insulin secre-

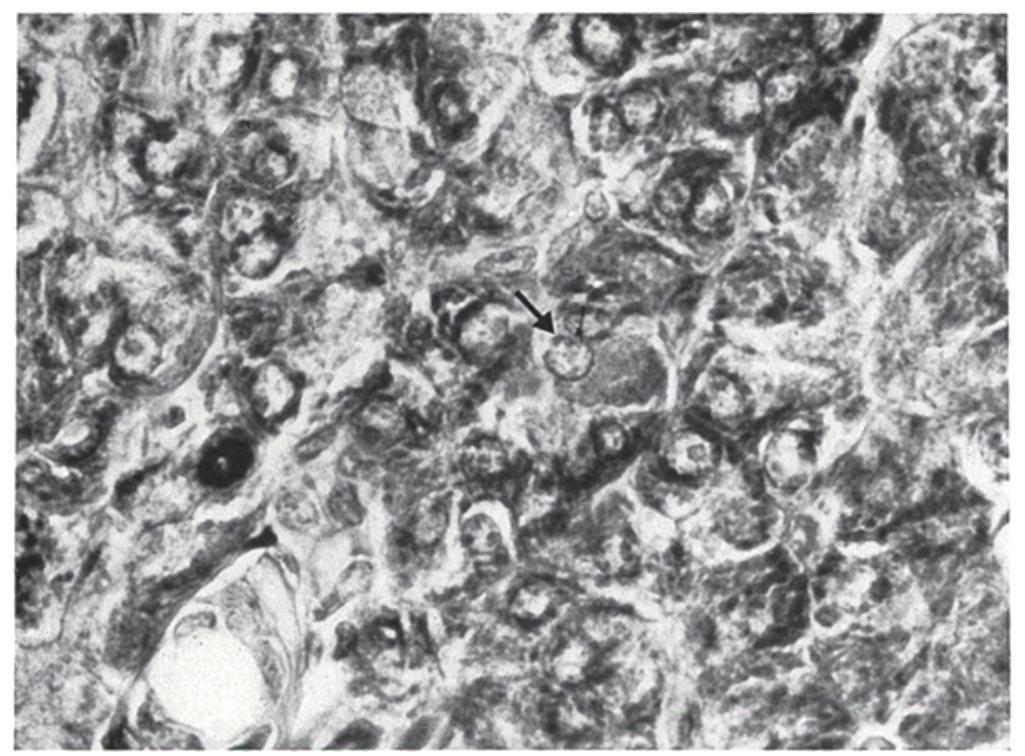

Fig. 5. Isolated B-cell (arrow), scattered among exocrine parenchyma. No. Ga 152. $65 \mathrm{mg} / \mathrm{kg}$ streptozotocin. $6 \%$ islet B-cells. Glucose $773 \mathrm{mg} / 100 \mathrm{ml}$. IRI $27 \mu \mathrm{U}$. Gomori-Runge, $800: 1$

cells in the control animals the difference was - 5.7\% (range -3.6 to $-7.9 \%$ ). In the islets of the case with the B-cell adenoma the mean nuclear diameter was the same as in the controls $(4.52 \pm 0.39$ units $)$ for tion. Thus B-cell regeneration from insular or islet neoformation from extrainsular cells play no significant role, where as all criteria for a marked cellular hypertrophy are present. In one animal a B-cell 
adenoma developed. This B-cell adenoma was not centred by tubular structures as in Boquist's case [2] of a short-time alloxan-diabetic chinese hamster. Mitoses appeared to be absent in the B-cells of our animals. Logothetopoulos [23] has, in fact, observed significant mitotic activity only in the early phase after streptozotocin injection (maximal in the first week). This activity was much less marked than in alloxantreated rats. Therefore, it seems that B-cell neoformation and B-cell proliferation do not occur. The existence of a second B-cell type, already observed by Arison et al. [1], with stronger granulation and less marked hyperplasia cannot be as yet explained by our results. These authors interpreted their findings as signs of regeneration. The point in favour of a B-cell neoformation in our study is the finding of some aldehydefuchsin-positive cells among the exocrine pancreatic cells in some cases. Whether these single cells secrete insulin remains to be clarified.

It is well known that in certain animal species, such as mice, guinea pigs and rabbits, but also in infants of diabetic mothers $[14,20,21,22,3,5,28]$ hyperglycaemia seems to be a stimulus for B-cell proliferation and neoformation. To our knowledge only Arison et al. [1] mention a slight regenerative activity in mild streptazotocin diabetic rats; Logothetopoulos et al. [23] found no indications for a sustained regeneration of $\mathrm{B}$-cells in streptozotocin-diabetic mice. Lazarow [21], on the

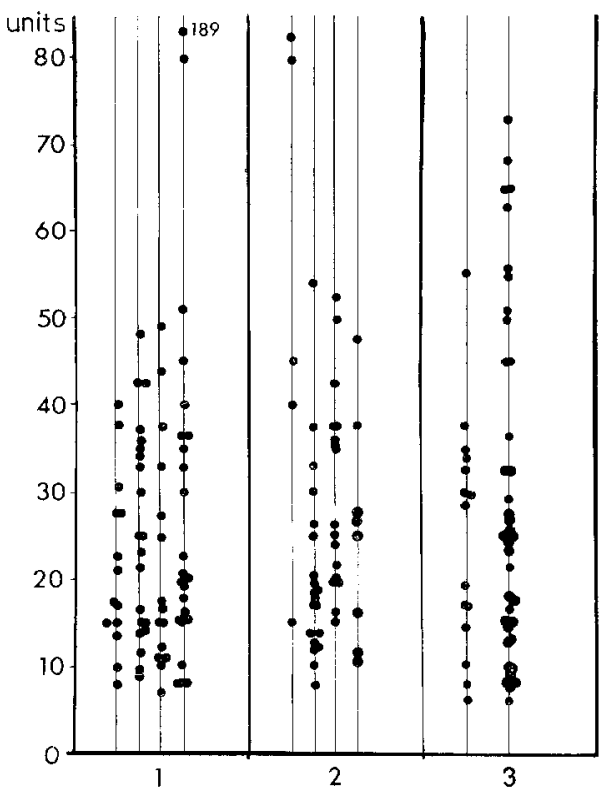

Fig. 6. Number and diameter of islets in comparable areas of pancreas. Each vertical bar represents one animal, each dot represents one islet. Diameters are given in arbitrary units and are corrected to spheres. Group I: $45-65 \mathrm{mg} / \mathrm{kg}$ streptozotocin, Group II: $85-100 \mathrm{mg} / \mathrm{kg}$, the bar to the right giving the case with the B-cell adenoma, the one to the left the case with partly paravenous injection. Group III : 2 control cases
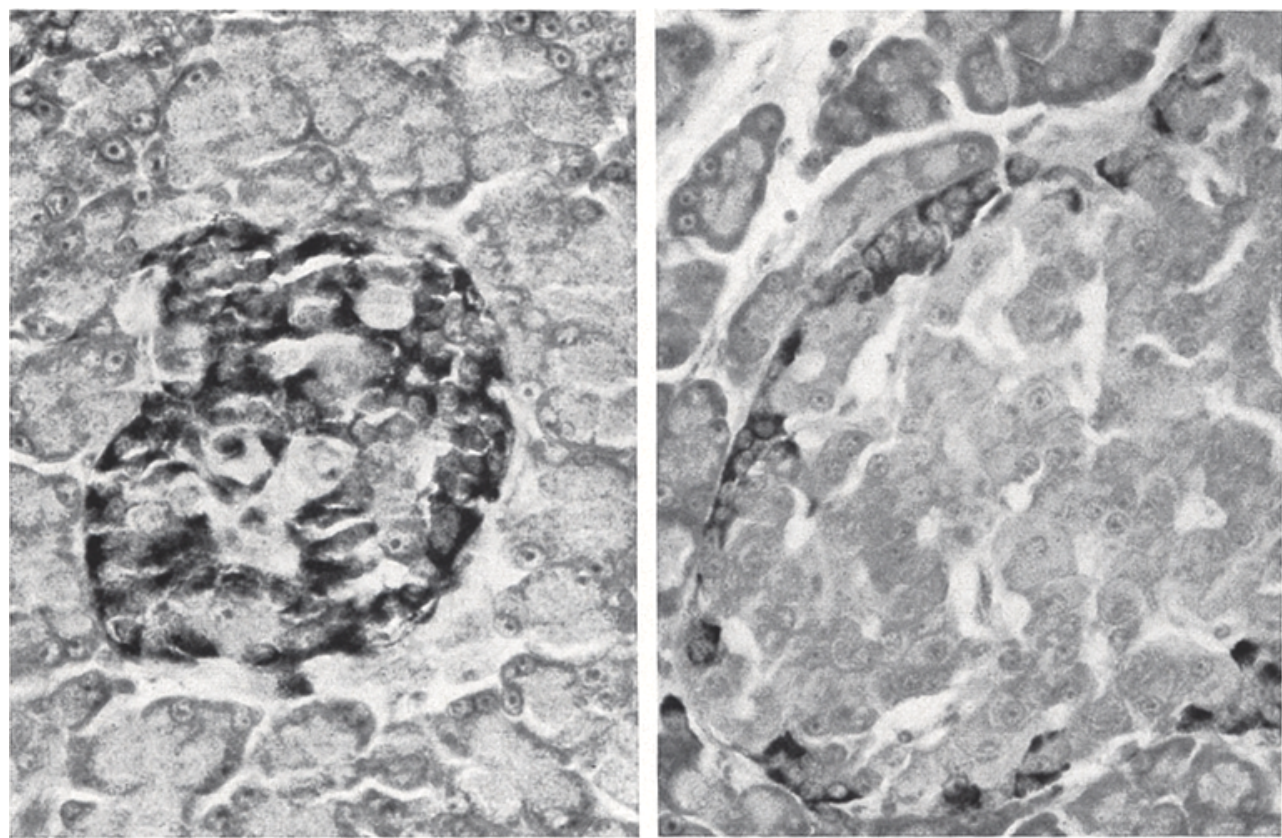

Fig. 7. Islet of Langerhans in control animal (left) and in diabetic animal (right) after $45 \mathrm{mg} / \mathrm{kg}$ streptozotocin. Predominance of $\mathrm{A}_{2}$-cells in irregular clusters and few degranulated B-cells in the latter. No. Ga 640 and 655 , Grimelius, $425: 1$

other hand, even observed remission from long-term alloxan diabetes in rats, and already in 1954 Kinah and Haist [19] reported on marked B-cell hyperplasia after chronic hyperglycaemia in this species. In dogs, islet neoformation and regeneration seems to be very unusual [22]. 
The metabolic abnormalities, i.e. hyperglycaemia, insulinopenia, polyuria and polyphagia are to be expected in the light of previous observations $[17,24]$. The plasma FFA were not extremely elevated, a finding which is quite characteristic for long-lasting diabetes with a loss of body fat. A marked relative increase of A-cells was present in all the cases and these cells were mostly classified as $\mathrm{A}_{2}$-cells. This has also been shown recently in guinea-pigs by Petersson et al. $[30,31]$. This group also found in isolated islets that oxygen uptake after incubation with D-glucose was less marked in the streptozotocin-treated group, whereas succinate markedly stimulated the oxygen uptake by these $A_{2}$-cell rich islets. The average diameters of the $A_{2}$ - and the B-cell-nuclei were significantly increased (Fig. 8a and b) which suggests an increased protein-synthetic activity $[15,28,26,34]$.

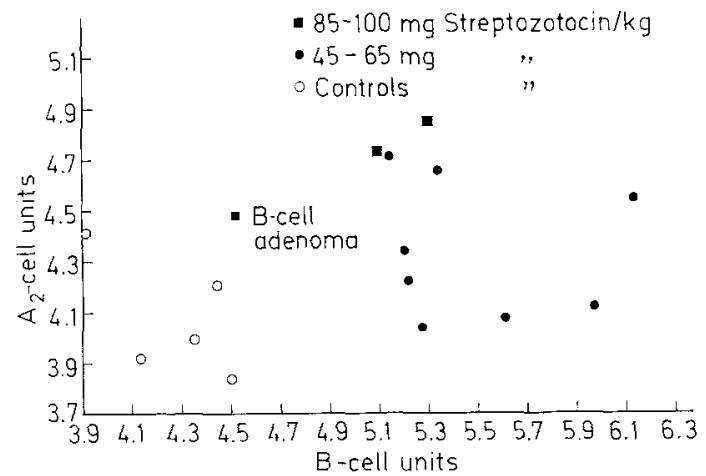

Fig. 8a. Correlation of $A_{2}$ - and B-cell nuclear diameters in streptozotocin-treated rats

Orci et al. [27] reported an increased number of lysosomal bodies which contain the specific $\alpha_{2}$-granules in $\mathrm{A}_{2}$-cells of streptozotocin-treated diabetic rats. The authors favour the hypothesis that this reflects destruction of unneeded glucagon. However, they discuss the possibility that this increase of lysosomes may have to do with solubilization of stored hormone prior to secretion or with a process favouring "cellular dedifferentiation returning the cell to a potentially more versatile state". Our results as well as those of Petersson's group $[30,31]$ seem to support the latter possibilities, because both $\mathrm{A}_{2}$ and B-cells seem to be quite active. In a normal individual, during a glucose tolerance test, pancreatic glucagon falls and gut glucagon in plasma increases almost simultaneously with the rise of the IRI [12]. Under this condition, gut glucagon does not seem to mobilize glucose but rather insulin. The same conclusion was drawn from the faster insulin release during oral than i.v. glucose tolerance test. Possibly other agents, such as secretin, may also play a role. Samols et al. [33], on the other hand, postulated that gut glucagon is primarily hyperglycaemic and pancreatic glucagon primarily insulinogenic and hyperglycaemic only in the second place; in vitro the insulin releasing action of pancreatic glucagon was demonstrated in rat pancreas even in the absence of glucose [4]. Under pathologic conditions, as in the present study, characterized by a strong insulinopenic hyperglycaemia, the pancreatic glucagonocytes seem to be very active and might be mainly $\beta$-cytotrophic. On the other hand, the duodenal glucagonocytes are neither increased nor activated. However, our quantitative results of the duodenal cell analysis are rather difficult to interpret, because at least one more cell type, the serotonin-cell, was also stained with the present method. The glycogen-mobilizing activity of glucagonocytes might be of importance even in these cases. In

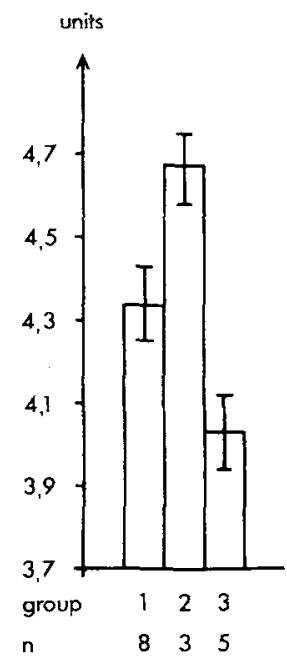

b. Mean diameters of $A_{2}$-cell nuclei

Group I: $\quad 45-65 \mathrm{mg} / \mathrm{kg}$ streptozotocin i.v., Group II : $85-100 \mathrm{mg} / \mathrm{kg}$ streptozotocin i.v., Group III: controls

7 units $=10 \mu$

$t 1$ versus $3<0.05$

$$
\delta=\frac{\mathrm{s}}{\mathrm{n}}
$$

$t 2$ versus $3<0.005$

eonclusion, there is rather good evidence for a low regenerative and neoformative activity of pancreatic B-cells in streptozotocin-diabetic rats. The remaining B-cells appear very active, possibly as a result of stimulation by the pancreatic glucagonocytes and/or high extracellular glucose concentration. The develop. ment of a functioning B-cell adenoma in one of the animals may be a consequence of chronic stimulation of a tissue which, otherwise, has lost its regenerative activity. On the other hand, we have no indications for an exhaustion of the B-cells.

Further studies are needed to answer the question whether the stimulation of the remaining B-cells is mediated through the $\mathrm{A}_{2}$-cells or the sustained hyperglycaemia in the streptozotocin-treated animals.

Acknowledgements: The authors wish to thank Dr. C. Hellerström, Uppsala, for his helpful criticism and Miss E. Weber, Miss N. Weber, and Mr. P. Perret for their valuable technical assistance. 


\section{Literature}

1. Arison, R. N., Ciaccio, E.I., Glitzer, M.S., Cassaro, J. A., Pruss, M.P.: Light and electron microscopy of lesions in rats rendered diabetic with streptozotocin. Diabetes 16, $51-56$ (1967).

2. Boquist, L.: Alloxan Administration in the Chinese Hamster. Virchows Arch. Abt. B. Zellpath. 1, 157168 (1968).

3. Cavallero, C.: Application de la méthode colchicinique à l'étude du diabète alloxanique chez le rat. Rev. belge Path. Méd. Expér. 18, 323-329 (1947).

4. Derrim, S., Recant, L. : Effect of glucagon on insulin release in vitro. Lancet $1966 \mathrm{H}, 1227-1228$.

5. Friedman, N.B., Marble, A.: Island hyperplasia in partially depancreatectomized rats. Endocrinology 29, $577-583(1941)$.

6. Funk, H.U., Weber, E., Hedinger, Chr., Hardmeier, Th.: Die Zahl der argentaffinen Zellen des menschlichen Verdauungstraktes unter normalen und pathologisehen Bedingungen. Virchows Arch. Path. Anat. $340,289-303(1966)$.

7. Gepts, W.: Pathologic anatomy of the pancreas in juvenile diabetes mellitus. Diabetes 14, 619-633 (1965).

8. Gordon, R.F., Cherkes, A., Gates, N.: Unesterified fatty acid in Human Blood Plasma. II. The transport function of unesterified fatty acid. J. elin. Invest $\mathbf{3 6}$ $810-815$ (1957).

9. Grimelius, L.: A silver nitrate stain for $A_{2}$ cells in human pancreatic islets. Acta Soc. Med. upsalien. 73 , $243-276(1968)$.

10. Hales, C.N., Randle, P.J.: Immunoassay of insulin with insulin-antibody precipitate. Biochem. J. 88, $137-146$ (1963). Lancet 1963 I, 200.

11. Hamperl, H.: Über die „gelben (chromaffinen) " Zellen im gesunden und kranken Magendarmschlauch. Virchows Areh. path. Anat. 266, 509--548 (1927).

12. Heding, L. : Determination of pancreatic and gut glucagon in plasma. Abstr. 5th annual meeting of the Europ. Assoc. for the study of Diabetes, Montpellier, 1969.

13. Hellerström, C., Hellman, B.: Some aspects of silver impregnation of the islets of Langerhans in the rat. Acta endocr. (Kbh.) 35, 518-532 (1960).

14. Hellman, B., Hellerström, C.: Histology and histophysiology of the islets of Langerhans in man. In: Diabetes mellitus, Vol. I, ed. E. F. Pfeiffer. München: Lehmann's Verlag 1968.

15. Hultquist, G.T.: Nuclear size in the cells of Langerhans' islets during starvation in the rat. Acta anat. 49, $281-287$ (1962)

16. Ivic, M. : Neue selektive Färbungsmethode der A- und B-Zellen der Langerhans'schen Inseln. Anat. Anz. 107, $347-350$ (1959).

17. Junod, A., Lambert, A.E., Orci, L., Pictet, R., Gonet, A.E., Renold, A.E.: Studies on the diabetogenic action of streptozotocin. Proc. Soc. exp. Biol. Med. 126, $201-205$ (1967).

18. Junod, A., Lambert, A.E., Stauffacher, W., Ronold, A. E.: Diabetogenic action of streptozotocin : Relationship of dose to metabolic response. J. clin. Invest. 48, $2129-2139(1969)$.
19. Kinash, B., Haist, R. E.: Continuous intravenous infusion in the rat, and the effect on the islets of Langer. hans of the continuous infusion of glucose. Canad. J. Biochem. Physiol. 32, 428-433 (1954).

20. Lazarow, A.: Spontaneous recovery from alloxan diabetes in the rat. Diabetes 1, 363-371 (1952).

21. Lazarus, S.S., Volk, B.W.: The effect of protracted glucagon administration on blood glucose and on pancreatic morphology. Endocrinology 63, 359-371 (1958).

22. - Volk, B.W.: The pancreas in human and experimental diabetes. N.Y. London: Grune and Stratton 1952.

23. Logothetopoulos, J., Rorosky, S.: Mitotic activity of islet cells in alloxan and streptozotocin diabetic mice studied by autoradiography. Diabetes 17, Suppl. 1, 306 (1968) Abstr.

24. Mansford, K.R.L., Opie, L.: Comparison of metabolic abnormalities in diabetes mellitus induced by streptozotocin or by alloxan. Lancet $1968 \mathrm{I}, 670-671$.

25. Mueller, I., Runge, W., Ferner, H. : Cytologie und Gefässverhältnisse des Inselorgans bei der Ente. Z. mikr.anat. Forsch. 62, 165-186 (1956).

26. Oehlert, W., Schultze, B.: Die Kerngröße als Ausdruck der synthetischen Aktivität des Kerns. Beitr. path. Anat. 123, $101-113$ (1960).

27. Orci, L., Junod, A., Renold, A.E., Rouiller, C.: Granulolysis in A-cells of endocrine pancreas in spontaneous and experimental diabetes in animals. J. cell Biol. 38, $462-466$ (1968).

28. Patent, G.J., Alfert, M.: Histological changes in the pancreatic islets of Alloxan treated mice, with comments on $\beta$-cell regeneration. Acta anat. 66, 504-519 (1967).

29. Pearse, A.G.E.: In: Histochemistry. London: A. Churchill 1961.

30. Petersson, B., Hellerström, C., Gunnarsson, R.: Metabolic studies of pancreatic A-cells. Abstr. annual meeting Europ. Assoc. for the study of Diab. Montpell. 1969.

31. - - - Structure and metabolism of the pancreatic islets in streptozotocin treated guinea-pigs. Hormone. Met. Res. 2, (1970), in press.

32. Rakieten, N., Rakieten, M.L., Nadkarni, M.V.: Studies on the diabetogenic action of streptozotocin (NSC37917). Cancer Chemoth. Rep. 29, 91-98 (1963).

33. Samols, E., Tyler, J., Megyesi, C., Marks, V.: Immunochemical glucagon in human pancreas, gut and plasma. Lancet 1966 II, $727-729$.

34. Steiner, H., Hedinger, Chr.: Storage of acidophilic granules in the pituitary in experimental hyperglycaemia. Diabetologia 6, 373-378 (1970)

35. Veleminsky, J., Burr, I., Gutzeit, A., Beaven, D., Stauffacher, W.: Streptozotocin-diabetes prevention by nicotinamide and comparisons with alloxan diabets. Abstr. annual meeting Europ. Assoc. for the study of Diab. Montpell. 1969.

Dr. H. Steiner

Institut d'Anatomie Pathologique

Université

CH-1011 Lausanne 